\title{
Morphological Adaptation of Cercis Griffithii Seedlings in Response to Progressive Drought and Salinity Stresses
}

\section{*11TABATABAEI, SAH; ${ }^{2}$ ESMAEILI SHARIF, M; ${ }^{3}$ BAGHERI, M; ${ }^{4}$ JALILVAND, H; ${ }^{5}$ AHANI, H}

\author{
${ }^{* 1}$ Faculty of Natural Resources, University of Agricultural Sciences and Natural Resources, Sari, Iran \\ ${ }^{2}$ Department of Forest Sciences, Research Division of Natural Resources, Isfahan Agricultural and Natural Resources Research and \\ Education Center, AREEO, Isfahan, Iran. \\ ${ }^{3}$ Department of Agriculture science, Islamic Azad University of Ardestan branch Ardestan, Isfahan, Iran, P O Box: 83815-117, Isfahan, Iran. \\ ${ }^{4}$ Department of Forestry (Silviculture and Forest Ecology), Faculty of Natural Resources, University of Agricultural Sciences and Natural \\ Resources, km10/Neka Road, P O Box 737, Sari, Iran. \\ ${ }^{5}$ Faculty of Environment and Natural Resources, Ferdowsi University of Mashhad, Natural resources and watershed administration of \\ Khorasan Razavi, Iran. \\ *Corresponding author Email: a.tabatabaei@stu.sanru.ac.ir,tabatabaei.h68@gmail.com
}

\begin{abstract}
The experiment for evaluate the effect of drought and salinity stresses on the morphological behaviours of Afghan redbud seedlings was done in Torogh nursery in Iran country. This study was conducted in a completely randomized design; without stress (tap common water in the nursery- EC $0.8 \mathrm{dS} \mathrm{m}^{-1}$ ), drought stress (four days a time irrigation) and salt treatment $\left(\mathrm{EC} 12.03 \mathrm{dS} \mathrm{m}^{-1}\right)$. During the summer, morphological traits were measured and calculated. Result showed that height seedling after 60th until 70th day significant at the $(p<0.05)$ level and significantly at $(p<0.01)$ levels at the end of growth period under the drought and salinity conditions. Leaf area at the end of growth, leaf area growth and leaf area reduced significantly at $(p<0.01)$ in comparison with control treatment. The result indicated that effect of time $\times$ drought interaction for height, diameter, number of leaves and leaf area was not significant. The result indicated that effect of time $\times$ salinity interaction for height, diameter and number of leaves was not significant but for leaf area had significant difference at $(p<0.05)$ level. We used four days a time by irrigation and saline water in nursery less than EC $12.03 \mathrm{dS} \mathrm{m}^{-1}$ for economy well water in arid and semi-arid region.
\end{abstract}

DOI: https://dx.doi.org/10.4314/jasem.v21i7.6

Copyright $@ 2017$ Tabatabaei et al. This is an open access article distributed under the Creative Commons Attribution License (CCL), which permits unrestricted use, distribution, and reproduction in any medium, provided the original work is properly cited

Received 15 July 2017; received in revised form 11 September 2017; accepted 03 December 2017

Keywords: Afghan redbud, Stress, Growth, Regression model, Repeated Measures

Drought and salinity, the major abiotic stresses, are the main factors determining global vegetation distribution in the forestry and agricultural sector. Plants are often exposed to environmental stresses through a life cycle. Water stress caused by high salinity and drought is one of the serious factors to limit plant productivity (Ueda et al., 2007).

Effects of salinity are more conspicuous in arid and semi-arid regions, which are characterized by limited rainfall, high evapotranspiration, and high temperature. Crucial changes in ion and water homeostasis caused by high concentrations of salts lead to damage at the molecular level, arrested growth, and even death. Salinity reductions can have particularly strong effects on distribution, behavior and survival in such environments (Tijen and Ismail, 2006).

The impact of drought on the hydraulic traits of plants has drawn increasing attention. According to the cohesion-tension theory (Steudle, 2001), water moves through the xylem under tension (negative pressure) during transpiration. Therefore, rapid transpiration during the drought season increases the risk of xylem cavitations.

Normally in several studies is proven to reduce the growth morphology of plants to drought and salinity stresses.

Griffin (2002) studied the effect of heat and drought on photosynthesis and water relations of Cercis canadensis var. canadensis and C. canadensis var. mexicana. Both ecotypes proved to be extremely drought resistant. The rate of net photosynthesis decreased at a similar rate in both ecotypes but Mexican redbud maintained generally greater net photosynthetic rates than eastern redbud. Mexican redbud also maintained greater water use efficiency under increasing drought than $C$. canadensis var. canadensis. It had a high rate of net photosynthesis and did not immediately reduce stomatal conductance during drought stress. It was also observed that the Mexican redbud tended to shed leaves under severe drought conditions. The frequently reported solute 
accumulation in drought stressed plants did not occur. Osmotic potential at full turgor was unaffected by drought in both redbud ecotypes. Tabatabaei et al., (2014a) study of drought stress response in Celtis caucasica Willd showed average height, number of leaves, leaf area, shoot length and leaf area ratio in the drought treatment was significant by stress condition. Tabatabaei et al., (2014b) in Celtis caucasica seedlings indicated that under salt stress (EC 12.03 dS $\mathrm{m}^{-1}$ ) height growth, number of leaves, leaf area at the end of growth period and leaf area growth were significantly different in comparison with control treatment. Results of repeated measures analysis showed that effect of time salinity interaction for diameter was not significant but for height and leaf area had significant difference.

The genus Cercis belongs to the subfamily Caesalpinioideae of the large plant family Fabaceae (Leguminosae-legume family). The genus Cercis currently includes ten recognized species scattered widely across the warm, north-temperate zones of North America and Eurasia (Fritsch et al., 2009). Cercis L. (Redbud or Judas tree) are trees or shrubs of small to medium size with alternate, undivided, heartto kidney-shaped, toothless leaves with five to nine conspicuous veins radiating from their base. Cercis griffithii, the Afghan redbud, is native to Afghanistan (Raulston, 1968) and described to be very similar to and considered by some an ecotype of $C$. siliquastrum (Raulston, 1990).

Islamic Republic of Iran is located at the arid and semi-arid region of Asia. Also, some global predicted map for 2025 showed that Iran will be in the driest classes' countries. Thereupon, study and various tests associated with forest trees are essential to the watereconomy, conservation and development of natural resources.The present work is the first study reporting salinity (water source of KavirPark-Civil Gonabad with EC $12.03 \mathrm{dS} \mathrm{m}^{-1}$ ) and drought stresses on the morphological traits of Cercis griffithii seedlings in the study region and world, which is essential for guiding future management strategies for economy well water and used salt water for irrigation resistance species.

\section{MATERIALS AND METHODS}

Experimental design: In this study the effect of drought and salinity stress on morphological characteristics Cercis griffithii Boiss. 1872 species that seed from accessions were used in Khorasan Razavi in Iran to produce the mother plants (Fig. 1). The experiment was carried out in Torogh nursery, Mashhad city (the length of $59^{\circ} 38^{\prime} 00^{\prime \prime}$ geographical
Eastern and $36^{\circ} 16^{\prime} 00^{\prime \prime}$ north latitude, altitude 990 meters and area is approximately 64 ha). Seedlings after transfer to pots containing sandy loam, up to three months in terms of the usual nursery of irrigation were in the well water treatment (every two days). Then physical experiments for determining relative particles (percentage of clay, silt and sand) were performed using the hydrometer Baykas on particles smaller than two $\mathrm{mm}$; tested soil characteristics are given (Table 1). From early summer treatments was conducted on $C$. griffithii seedlings to the drought conditions (four days a time by irrigation), salinity stress (water source of KavirPark-Civil Gonabad with EC $12.03 \mathrm{dS} \mathrm{m}^{-1}$ in table 1) and without stress (a common method of irrigation nursery two days, each time $150 \mathrm{ml} \mathrm{day}^{-1}$.). This study was conducted in a completely randomized design with eight replicates during the summer (dry part of growth season).

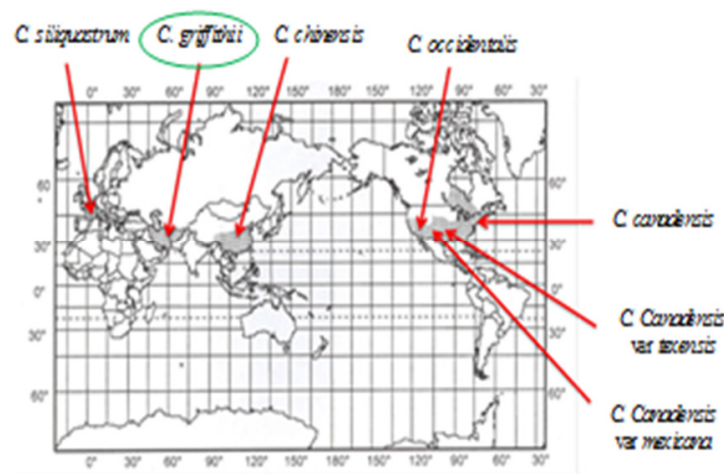

Fig. 1: Map of Khorasan Razavi in Iran Khorasan Razavi in Iran

Measurement of growth parameters: Stem growth characteristics were every ten days monitored by measuring length (from substrate surface to the apical meristem), diameter (at the base) and by counting the number of leaves and leaf area per month, so that the base of each treatment, five selection seedling and each seedling five leaf selection of basic randomized to using AutoCAD 2013 software, in meters squared size was measured. Three plants were harvested at the end of the experiment in early fall and divided into leaves, stem and roots fresh weight was calculated. Biomass samples were dried $\left(70^{\circ} \mathrm{C}, 48 \mathrm{~h}\right)$ to constant and weighed.

Root to shoot ratio between the shoot and root dry weight. Leaves to shoot ratio to obtain the dry weight of the leaves and shoot, the ratio was calculated. Leaf area ratio an index of the amount of spilled leaves the plant. For each plant the ratio between total leaf area and dry weight. The quotient is the ratio of leaf area, but the term has become more common. Specific leaf area is a measure of leaves. For each plant the ratio between total leaf areas and total dry weight of leaves. 
Leaf weight ratio is a measure between the total dry weight of leaves and total dry weight (Karimi and Azizi, 1994) and Slenderness index between height average to diameter average (Taheri Abkenar and Pilehvar, 2009).

Statistical methods: The experiment was arranged in the base of completely randomized design. The normality tested by (Kolmogorov-Smirnov) using SPSS version 19. Data collected were subjected to Analysis of Variance (ANOVA); mean comparison was carried out using Duncan multiple comparison tests with significant results were assumed for $p \leq 0.05$, replication analysis measurements of height, diameter, leaf number in ten and leaf area in three time times calculated with four different multivariate tests (Wilks' Lambda, Pillai's Trace, Hotelling-Lawley Trace and
Roy's Greatest Root) and ANOVA of nonlinear regression using the statistical software SAS version of the 9.1. Diagrams were drawn using the Excel software for growth average between height, diameter, leaf number and leaf area was conducted by stress condition initiation until end of the experiment.

\section{RESULTS AND DISCUSSION}

Analysis of variance indicated those terms of height seedling in $60^{\text {th }}$ and $70^{\text {th }}$ day significant at the 0.05 and $80^{\text {th }}$ and $90^{\text {th }}$ at the 0.01 level and 0.05 level in leaf area growth, leaf area ratio and leaf area under the drought and salinity conditions. Results the comparison mean indicated that in all traits has significant decreased in the drought and salinity stress as compared with control (Table 2).

Table 1- Characteristics of soils in $(0-30 \mathrm{~cm})$ experiment start and source water KavirPark-Civil Gonabad

\begin{tabular}{|c|c|c|c|c|c|c|c|c|c|c|c|}
\hline \multicolumn{12}{|c|}{ Soil properties } \\
\hline $\mathrm{pH}$ & $\begin{array}{c}\mathrm{EC} \\
(\mathrm{dS} / \mathrm{m})\end{array}$ & $\begin{array}{c}\text { bulk density } \\
\left(\mathrm{g} / \mathrm{m}^{3}\right)\end{array}$ & $\begin{array}{c}\text { Soil } \\
\text { texture }\end{array}$ & $\begin{array}{l}\text { Sand } \\
(\%)\end{array}$ & $\begin{array}{l}\text { Silt } \\
(\%)\end{array}$ & $\begin{array}{l}\text { Clay } \\
(\%)\end{array}$ & $\begin{array}{c}\text { Organic matter } \\
(\%)\end{array}$ & $\begin{array}{c}\text { Moisture } \\
(\%)\end{array}$ & $\begin{array}{c}\mathrm{P} \\
(\mathrm{mg} / \mathrm{kg})\end{array}$ & $\begin{array}{c}\mathrm{K}^{+} \\
\mathrm{mg} / \mathrm{kg})\end{array}$ & - \\
\hline 7.4 & 6.61 & 1.42 & $\begin{array}{l}\text { Sandy } \\
\text { loam }\end{array}$ & 67 & 23 & 10 & 1.04 & 9.8 & 54.8 & 353 & - \\
\hline \multicolumn{12}{|c|}{ Water properties } \\
\hline \multirow[t]{2}{*}{$\mathrm{pH}$} & $\begin{array}{l}\text { E.C. }{ }_{w} \\
(\mathrm{dS} / \mathrm{m})\end{array}$ & \multicolumn{2}{|c|}{$\begin{array}{c}\text { Soluble cations } \\
\text { (me/l) }\end{array}$} & & & & $\begin{array}{c}\text { soluble anions } \\
(\mathrm{me} / \mathrm{l})\end{array}$ & & & & \\
\hline & & $\mathrm{Ca}^{+2}+\mathrm{Mg}^{+2}$ & $\mathrm{Ca}^{+2}$ & $\mathrm{Mg}^{+2}$ & $\mathrm{Na}^{+}$ & $\mathrm{K}^{+}$ & $\mathrm{HCO}_{3}{ }^{-}+\mathrm{CO}_{3}{ }^{-2}$ & $\mathrm{CO}_{3}^{-2}$ & $\mathrm{HCO}_{3}{ }^{-}$ & $\mathrm{SO}_{4}^{-2}$ & $\mathrm{SO}_{4}{ }^{-2}$ \\
\hline 7 & 12.0 & 20 & 10.7 & 9.3 & 101. & 0 & 3.7 & Non & 3.7 & 50 & 67 \\
\hline
\end{tabular}

Table 2- ANOVA results and mean comparisons morphological traits; Mean \pm SE.

\begin{tabular}{ccccccc}
\hline $\begin{array}{c}\text { Morphological } \\
\text { traits }\end{array}$ & Day & $\begin{array}{c}\text { Mean } \\
\text { Square }\end{array}$ & $\begin{array}{c}\text { F- } \\
\text { value }\end{array}$ & Control & drought & Salinity \\
\hline & $60^{\text {th }}$ & 34.12 & $4.67^{*}$ & $18.75 \pm 0.83^{\mathrm{A}}$ & $16.50 \pm 0.73^{\mathrm{AB}}$ & $14.62 \pm 1.22^{\mathrm{B}}$ \\
Height $(\mathrm{cm})$ & $70^{\text {th }}$ & 38.54 & $5.13^{*}$ & $19.00 \pm 0.88^{\mathrm{A}}$ & $16.50 \pm 0.73^{\mathrm{AB}}$ & $14.62 \pm 1.22^{\mathrm{B}}$ \\
& $80^{\text {th }}$ & 46.17 & $6.66^{* *}$ & $19.00 \pm 0.84^{\mathrm{A}}$ & $16.50 \pm 0.73^{\mathrm{B}}$ & $14.75 \pm 1.22^{\mathrm{B}}$ \\
& $90^{\text {th }}$ & 48.79 & $6.77^{* *}$ & $19.62 \pm 0.90^{\mathrm{A}}$ & $16.50 \pm 0.73^{\mathrm{B}}$ & $14.75 \pm 1.22^{\mathrm{B}}$ \\
Leaf area growth & - & 181.29 & $2.99^{*}$ & $2.25 \pm 4.24^{\mathrm{A}}$ & $-3.87 \pm 1.52^{\mathrm{AB}}$ & $-7.12 \pm 1.56^{\mathrm{B}}$ \\
Leaf area ratio & - & 0.000019 & $12.43^{*}$ & $0.007 \pm 0.0012^{\mathrm{A}}$ & $0.002 \pm 0.00036^{\mathrm{B}}$ & $0.002 \pm 0.00079^{\mathrm{B}}$ \\
Leaf area $\left(\mathrm{m}^{2}\right)$ & 3rd month & 0.00015 & $4.42^{*}$ & $0.017 \pm 0.0037^{\mathrm{A}}$ & $0.009 \pm 0.0013^{\mathrm{AB}}$ & $0.006 \pm 0.0023^{\mathrm{B}}$ \\
\hline
\end{tabular}

Table 3- Analysis of multivariate tests in effect treatment $\times$ time morphological traits treatment

\begin{tabular}{|c|c|c|c|c|c|}
\hline Treatment & $\begin{array}{l}\text { Morphological } \\
\text { traits }\end{array}$ & $\begin{array}{l}\text { Wilks' } \\
\text { Lambda } \\
\end{array}$ & $\begin{array}{l}\begin{array}{l}\text { Pillai's } \\
\text { Trace }\end{array} \\
\end{array}$ & $\begin{array}{l}\text { Hotelling-Lawley } \\
\text { Trace }\end{array}$ & $\begin{array}{l}\text { Roy's Greatest } \\
\text { Root }\end{array}$ \\
\hline \multirow{8}{*}{ Control-Drought } & \multirow{2}{*}{ Height $(\mathrm{cm})$} & 0.60 & 0.39 & 0.66 & 0.66 \\
\hline & & $1.33^{\mathrm{ns}}$ & $1.33^{\mathrm{ns}}$ & $1.33^{\mathrm{ns}}$ & $1.33^{\mathrm{ns}}$ \\
\hline & \multirow{2}{*}{ Diameter $(\mathrm{mm})$} & 0.73 & 0.26 & 0.36 & 0.36 \\
\hline & & $0.72^{\mathrm{ns}}$ & $0.72^{\mathrm{ns}}$ & $0.72^{\mathrm{ns}}$ & $0.72^{\mathrm{ns}}$ \\
\hline & \multirow{2}{*}{ No. of leaves } & 0.03 & 0.96 & 28.45 & 28.45 \\
\hline & & $7.11^{\mathrm{ns}}$ & $7.11^{\mathrm{ns}}$ & $7.11^{\mathrm{ns}}$ & $7.11^{\mathrm{ns}}$ \\
\hline & \multirow{2}{*}{ Leaf area $\left(\mathrm{m}^{2}\right)$} & 0.53 & 0.46 & 0.87 & 0.87 \\
\hline & & $3.06^{\mathrm{ns}}$ & $3.06^{\mathrm{ns}}$ & $3.06^{\mathrm{ns}}$ & $3.06^{\mathrm{ns}}$ \\
\hline \multirow{8}{*}{ Control-Salinity } & \multirow{2}{*}{ Height $(\mathrm{cm})$} & 0.39 & 0.60 & 1.51 & 1.51 \\
\hline & & $1.73^{\mathrm{ns}}$ & $1.73^{\mathrm{ns}}$ & $1.73^{\mathrm{ns}}$ & $1.73^{\mathrm{ns}}$ \\
\hline & \multirow{2}{*}{ Diameter (mm) } & 0.78 & 0.21 & 0.28 & 0.28 \\
\hline & & $0.56^{\mathrm{ns}}$ & $0.56^{\mathrm{ns}}$ & $0.56^{\mathrm{ns}}$ & $0.56^{\mathrm{ns}}$ \\
\hline & \multirow{2}{*}{ No. of leaves } & 0.23 & 0.76 & 3.20 & 3.20 \\
\hline & & $0.80^{\text {ns }}$ & $0.80^{\mathrm{ns}}$ & $0.80^{\text {ns }}$ & $0.80^{\mathrm{ns}}$ \\
\hline & \multirow[t]{2}{*}{ Leaf area $\left(\mathrm{m}^{2}\right)$} & 0.38 & 0.61 & 1.57 & 1.57 \\
\hline & & $5.50 *$ & $5.50 *$ & $5.50 *$ & $5.50 *$ \\
\hline
\end{tabular}

ns: Not significant and $* \mathrm{p}<0.05$. The number of second rows for each term showed statistics equivalent $\mathrm{F}$.

Table 4- Nonlinear regression model growth for morphological traits

\begin{tabular}{llllll}
\hline Morphological traits & Treatment & $\mathrm{R}^{2}$ & $\mathrm{R}$ & Std. error & $\mathrm{VIF}$ \\
\hline \multirow{3}{*}{ Height $(\mathrm{cm})$} & Control & $93.50 \%$ & 0.96 & 0.55 & 1.0 \\
& Drought & $87.41 \%$ & 0.93 & 0.21 & 1.0 \\
& Salinity & $81.86 \%$ & 0.90 & 0.08 & 1.0 \\
Diameter (mm) & Control & $97.64 \%$ & 0.98 & 0.02 & 1.0 \\
& Drought & $91.67 \%$ & 0.96 & 0.01 & 1.0 \\
& Salinity & $97.20 \%$ & 0.98 & 0.01 & 1.0 \\
No. of leaves & Control & $57.93 \%$ & 0.76 & 0.53 & 1.0 \\
& Drought & $62.55 \%$ & 0.79 & 0.15 & 1.0 \\
& Salinity & $93.69 \%$ & 0.97 & 0.64 & 1.0 \\
\hline
\end{tabular}

Tabatabaei, SAH; Esmaeili, SM; Agheri, M; Jalilvand, H; Ahani, H 
Repeated measures analysis of such statistics, Wilks' Lambda, Pillai's Trace, Hotelling-Lawley Trace and Roy's Greatest Root of the timextreatment morphology traits of the measures indicated that the height, diameter, leaf number and leaf area of the control-drought treatment there is no significant difference; and indicated that the height, diameter and leaf number of the control-salinity treatment there is no significant difference but in leaf area showed significant differences at the 0.05 level (Table 3 ).

End of the growth period showed average height and diameter growth, leaf number and leaf area in drought and salinity stresses value of decrease. Height growth in drought and salinity in $60^{\text {th }}$ day decrease significantly $(p=0.0210)$ as compared with control treatment and the end of the experiment period showed significant $(p<0.0001, \quad p=0.0004$ and $p=0.0106)$ control, drought and salinity treatments, respectively. In controls showed a diameter growth from beginning
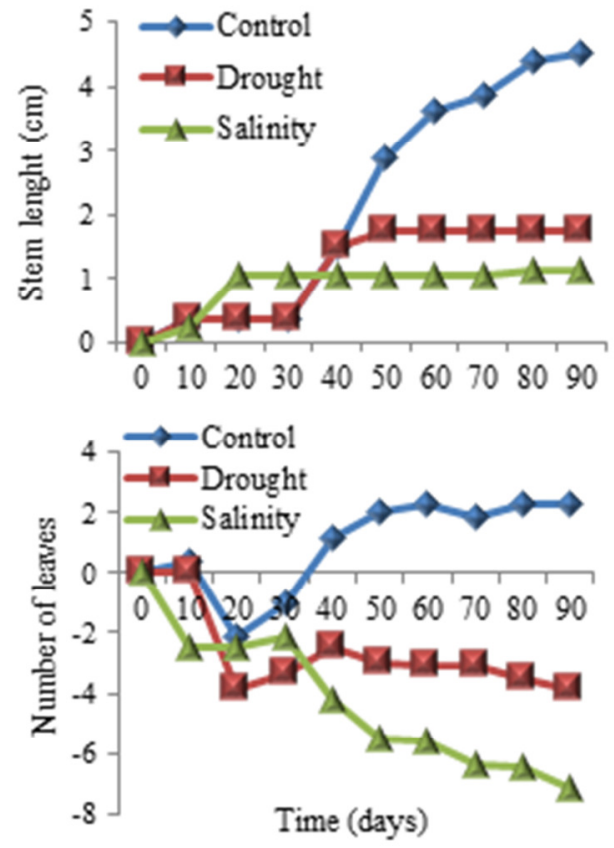

to end of the experiment increase gradually significant $(p<0.0001)$ in three treatments. Effect of leaf fall from beginning to end of the experiment period was significant indicated $(p=0.0108, \quad p=0.0312$ and $p<0.0001)$ in control, drought and salinity treatments, respectively and decrease leaf area in drought and salinity stresses as compared with non-stress treatment showed significant in third month $(p=0.0365)$ between control, drought and salinity treatments, respectively.

As it has been shown is in (Table 4) the final nonlinear regression model, the coefficient of determination, correlation coefficient, standard deviation error and variance inflation factor without stress and drought and salinity stresses treatments for morphological traits characters of height, diameter and leaf number. Polynomial growth curve with a slope showed, reducing the impact of drought and salinity on growth traits height, diameter, leaf number and leaf area (Fig. 2).
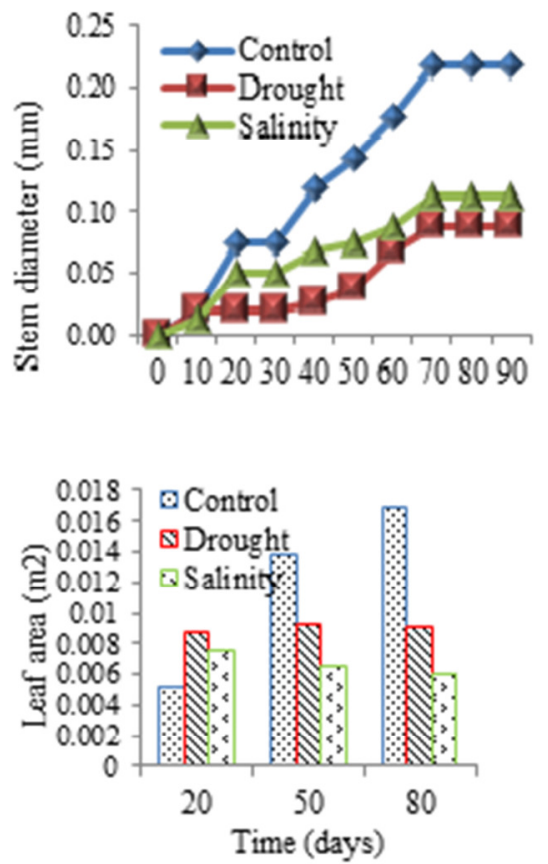

Fig. 2: Average growth rates over time for stem length, stem diameter, leaf number and leaf area of C. griffithii subjected to varying effect of drought stress. Day 0 represents the first day the experimental treatments were applied

Effects of drought stress on morphological traits: In this study it was observed that the heights, leaf area, and specific leaf area in drought and salinity stresses compared to the control decreased significantly.

Stem length was decreased in seedlings under drought stress. Similar results were observed in Populus $x$ euramericana seedlings (Marron et al., 2002) and Celtis caucasica seedlings (Tabatabaei et al., 2014a).
Leaf area was decreased in pine seedlings (Sword Sayer et al., 2005).

Reduction in shoot length, leaf area and plant dry weight and leaf fall signs of growth decrease is a drought stress response. The lack of moisture in the soil water osmotic potential becomes more negative Shoots and leaves when water is supplied to the roots, 
as they continue to grow. Also materials provide the root from the shoot, as they continue to grow. In case of water shortage, the balance was change and reduced leaf number but photosynthetic activity, to be comforted are less affected (Jalili Marandi, 2010). In dry conditions the less growth fluffs on the leaf epidermis. The number of stomatal per unit leaf area increases. Reduction in leaf area as soil water becomes limiting is achieved through reduction in leaf size, leaf rolling or leaf shedding, thus reducing the transpiring leaf surface, but with significant negative impact on carbon gain and overall plant productivity (Jones, 1992).

Leaf fall can be caused by water shortages and reduce the level of transpiration way to resist is dry. This increase in plant adaptation to drought; ethylene produced by stress, such as a secondary messenger for reactions to plant operation. Ethylene synthesis could be a dominant process and increasing density polyethylene reduced auxin transport in the petiole of the leaf area is subject to separate. Leaf fall reduced leaf area and the operation of the plant efficiently susceptible to water balance (Jalili Marandi, 2010).

Effects of salinity stress on morphological traits: Salinity had effects on morphological parameters such plant height, number of leaves, root length and shoot to root ratio etc.

The roots and shoots length are important parameters in plant. Because of roots have direct contact with soil and absorb water from the soil and shoot conduct it to the parts of the plant. Therefore, length of shoots and roots is a good scale for responses of plant to salinity.

Thus salinity reduces growth, cell size and the result due to exit of water from the plant cell and reduced the size of plant organs (Baghbani et al., 2013).

The conduction of field trial in a salinity area is one of the most important practices to evaluate the salttolerant ability of many plant species such as poplar (Sixto et al., 2005), Eucalyptus (Morris et al., 2006) and Celtis caucasica seedlings (Tabatabaei et al., 2014b).

When a plant is exposed to high salinity, its major processes such as photosynthesis, protein synthesis, and energy and lipid metabolism are affected. Crucial changes in ion and water homeostasis caused by high concentrations of salts lead to damage at the molecular level, arrested growth, and even death (Tijen and Ismail, 2006). The plant hormone abscisic acid (ABA) plays a critical role in responses to drought and high salinity stress signals. It is thought that osmotic stress imposed by high salt or drought is transmitted through at least two pathways; one is ABA-dependent and the other ABA independent (Mahajan and Tuteja, 2005).

Conclusion: In summary, it is concluded that water management influence on the quality of Judas tree (Cercis griffithii Boiss. 1872) seedlings, as it altered morphological characteristics. All of the above result indicated that drought and salinity stresses significantly affected relative heights, leaf area and leaf area ratio in drought and salinity stresses compared to the control decreased. Long term studies on performance of dormant and growing seedlings under drought and salinity treatment on actual forest regeneration sites are needed before recommendations can be made. Thus, we used four days a time by irrigation of $150 \mathrm{~mL}$ day $^{-1}$ and saline water less than EC $12.03 \mathrm{dS} \mathrm{m}^{-1}$ in nursery for economy well water in arid and semi-arid region. However need to do other tests such as physiology parameter (i.e. Water Use Efficiency, Relative Water Content, Water Potential, Water Saturation Deficit, Chlorophyll content and Photosynthetic of leaves); because the morphological indicators studied here were not able to clearly explain the differences in drought and salt tolerance.

Acknowledgements: The authors would like to thank the following people for supported by master forestry management and afforestation the department of watershed and the natural resources of the province Razavi Khorasan city of Mashhad, Mr. Soltani and of the Honorable responsible Torogh nursery of Mashhad, Mr. Ghazi.

\section{REFERENCES}

-Baghbani, A; Forghani, AH; Kadkhodaie, A (2013). Study of Salinity Stress on Germination and Seedling Growth in Greenhouse Cucumber Cultivars. Journal of Basic and Applied Scientific Research 3(3): 1137-1140.

-Coskun, F (2003). How closely related Turkish and North American red buds (Cercis-Fabaceae) are: Evidence from internal transcribed spacer region of nuclear ribosomal DNA sequences. Balıkesir Üniversitesi Fen Bilimleri Enstitüsü Dergisi 5(2): 24-37

-Fritsch, PW; Schiller, AM; Larson, KW (2009). Taxonomic Implications of morphological variation in Cercis canadensis (Fabaceae) from Mexico and adjacent part of Texas. Syst. Bot. 34: 510-520.

-Griffin, JJ (2002). Interactive Effects of Environmental Stresses on Photosynthesis. 
Dissertation, North Carolina State University, Raleigh, NC.

-Jalili Marandi, R (2010). Environmental stress physiology and mechanisms of resistance in horticultural plants. Urumie, Jahad University Press, p.636 (In Persian).

-Jones, HG (1992). Plants and microclimate: a quantitative approach to environmental plant physiology. 2nd Edn. Cambridge Univercity. Press, Cambridge, p. 428.

-Karimi, M; Azizi, M (1994). Analysis of crop growth. Jahad Mashhad University Press, p.111 (In Persian).

-Mahajan, S; Tuteja, N (2005). Cold, salinity and drought stresses: an overview. Arch. Biochem. Biophys. 444: 139-158.

-Marron, N; Delay, D; Petit, JM; Dreyer, E; Kahlem, G; Delmotte, FM; Brignolas, F (2002). Physiological traits of two Populus $x$ euramericana clones, Luisa Avanzo and Dorskamp, during a water stress and re-watering cycle. Tree Physiol. 22(12): 849-858.

-Morris, J; Collopy, J; Mahmood, K (2006). Canopy conductance and water use in Eucalyptus plantations. Pakistan J. Bot. 38: 1485-1490.

-Raulston, JC (1986). Plants in the NCSU Arboretum - Cercis (redbuds). North Carolina State University Arboretum, July 1986, No. 14.

-Raulston, JC (1990). Redbud. Am. Nurseryman 171: 39-51

-Sixto, H; Grau, JM; Alba, N; Alia, R (2005). Response to sodium chloride in different species and clones of genus Populus L. Forest 78: 93104.

-Steudle, E (2001). The cohesion-tension theory mechanism and the acquisition of water by plant roots. Annu. Rev. Plant Physiol. Plant Mol. Biol. 52: 847-875.

-Sword Sayer, MA; Brissette, JC; Barnett, JP (2005). Root growth and hydraulic conductivity of southern pine seedlings in response to soil temperature and water availability after planting. New Forest. 30: 253-272.

-Tabatabaei, SAH; Jalilvand, H; Ahani, H (2014a). Drought stress response in caucasian hackberry: growth and morphology. J. Bio. Env. Sci. 5(3): 158-169.

-Tabatabaei, SAH; Jalilvand, H; Ahani, H (2014b). Morphological response of Celtis caucasica Willd. seedlings to salinity stress in nursery. Arid Biome Scientific and Research Journal 4(2): 5466.

-Taheri Abkenar, K; Pilehvar, B (2008). Silviculture with a dictionary of silviculture (French-English to Persian Equivalents). Haghshenass publication, p.223 (In Persian).

-Tijen, D; Ismail, T (2006). Exogenous glycinebetaine affects growth and proline accumulation and retards senescence in two rice cultivars under $\mathrm{NaCl}$ stress. Environ. Exp. Bot. 56: 72-79.

-Ueda, A; Yamamoto-Yamane, Y; Takabe, T (2007). Salt stress enhances proline utilization in the apical region of barley roots. Biochem. Bioph. Res. Co. 355: 61-66. doi:10.1016/j.bbrc.2007.01.098. 